\title{
DNA vaccination against a fish rhabdovirus promotes an early chemokine-related recruitment of $B$ cells to the muscle
}

\author{
Rosario Castro ${ }^{a}$, Susana Martínez-Alonso ${ }^{a}$, Uwe Fischer ${ }^{b}$, Neila Álvarez de Haro ${ }^{c}$, \\ Verónica Soto-Lampe $^{\mathrm{b}}$, Tiehui Wang ${ }^{\mathrm{d}}$, Christopher J. Secombes ${ }^{\mathrm{d}}$, Niels Lorenzen ${ }^{\mathrm{e}}$, \\ Ellen Lorenzen ${ }^{\mathrm{e}}$, Carolina Tafalla ${ }^{\mathrm{a}, *}$
}

a Centro de Investigación en Sanidad Animal (CISA-INIA), Valdeolmos, Madrid, Spain

${ }^{\mathrm{b}}$ Friedrich-Loeffler-Institut, Federal Research Institute for Animal Health, Insel Riems, Greifswald, Germany

c Área de Biología Celular, Universidad de León, León, Spain

d Scottish Fish Immunology Research Centre, University of Aberdeen, Aberdeen, UK

e Department of Animal Science, Aarhus University, DK-8200 Aarhus, Denmark

\section{A R T I C L E I N F O}

\section{Article history:}

Received 23 September 2013

Received in revised form 8 November 2013

Accepted 15 November 2013

Available online 27 November 2013

\section{Keywords:}

DNA vaccine

Viral haemorrhagic septicaemia virus

(VHSV)

Teleost fish

B cells

Chemokines

Chemokine receptors

\begin{abstract}
A B S T R A C T
In fish, intramuscular (i.m) injection of plasmid DNA encoding viral proteins has proved a highly effective vaccination strategy against some viral pathogens. The efficacy of DNA vaccination in teleost fish is based on the high level of viral antigen expression in muscle cells inducing a strong and long-lasting protection. However, the mechanisms through which this protection is established and effectuated in fish are still not fully understood. Moreover, similarities to mammalian models cannot be established since DNA vaccination in mammals usually induces much weaker responses. In this work, we have focused on the characterization of the immune cells that infiltrate the muscle at the site of DNA injection in vaccinated fish and the chemokines and chemokine receptors that may be involved in their infiltration. We have demonstrated through diverse techniques that $\mathrm{B}$ lymphocytes, both $\mathrm{IgM}^{+}$and $\operatorname{IgT}^{+}$ cells, represented a major infiltrating cell type in fish vaccinated with a viral haemorrhagic septicaemia virus (VHSV) glycoprotein-encoding DNA vaccine, whereas in control fish injected with an oil adjuvant mainly granulocyte/monocyte-type cells were attracted. Among twelve chemokine genes studied, only CXCL11_L1, CK5B and CK6 mRNA levels were up-regulated in DNA vaccinated fish compared to fish injected with the corresponding vector backbone. Furthermore, the transcription of CXCR3B, a possible receptor for CXCL11_L1 was also significantly up-regulated in vaccinated fish. Finally, experiments performed with recombinant trout CK5B and CK6 and chemokine expression plasmids revealed that these chemokines have chemotactic capacities which might explain the recruitment of B cells to the site of DNA injection. Altogether, our results reveal that there is an early chemokine-related $B$ cell recruitment triggered by i.m. DNA vaccination against VHSV which might play an important role in the initial phase of the immune response.
\end{abstract}

(c) 2013 Elsevier Ltd. All rights reserved.

\section{Introduction}

DNA vaccination has proved as an effective method for inducing a potent and long-lasting protection against different fish viruses, especially rhabdoviruses such as infectious hematopoietic necrosis virus (IHNV) or viral haemorrhagic septicaemia virus (VHSV) [1-4]. Significant protection levels have also been achieved with DNA vaccines constructed for other fish viruses [5-7]. Concerning IHNV and VHSV vaccination in rainbow trout (Oncorhynchus mykiss), a single intramuscular (i.m.) injection of a naked DNA plasmid

\footnotetext{
* Corresponding author. Tel.: +34 91 6202300; fax: +34 916202247.

E-mail address: tafalla@inia.es (C. Tafalla).
}

coding for the glycoprotein $\mathrm{G}$ is capable of providing fish with full long-lasting protection $[8,9]$ and in consequence, one of the very few antiviral vaccines licensed for fish is an IHNV DNA vaccine [10]. Although a non-specific protection state elicited at early times post-vaccination seems to correlate with the induction of type I interferon (IFN) [9], the mechanisms through which these vaccines confer specific long-term protection are still not clear. Both humoral [9] and cellular [11] responses are triggered, but are not clearly correlated with protection.

Many studies have addressed the transcriptional response to vaccination in the spleen or head kidney $[12,13]$, but not many have focused on studying what happens at the injection site. This early local response should dictate all the downstream mechanisms elicited, being likely key for the outcome of the later systemic 
response. The genes modulated in the muscle after injection were studied for an IHNV DNA vaccine [14], demonstrating up-regulation of genes predominantly related to IFN. Additionally, in the context of an extensive characterization of the kinetics of VHSV G-protein expression in the membrane of myocytes in response to DNA vaccination, a significant infiltration of leukocytes around the injection site was described [15]. However, the nature of immune cells was not clearly established.

In rainbow trout, three different immunoglobulins (Igs) have been reported [16-18], which render two main subpopulations of central B cells, $\operatorname{IgM}^{+}$cells and $\operatorname{IgT}^{+}$cells. Although it seems that $\operatorname{IgT}^{+}$ cells play an important role in mucosal responses [19], recent evidence implicates IgT in systemic responses as well [20]. Our results demonstrate that both $\operatorname{IgM}^{+}$and $\operatorname{IgT}^{+}$cells are recruited to the muscle upon DNA vaccination, in contrast to reports in mammals, in which macrophages, $\mathrm{T}$ cells and neutrophils are the predominant recruited cell types $[21,22]$. To gain an insight into the mechanisms responsible for this $\mathrm{B}$ cell mobilization, we have also studied the transcription of a wide range of chemokine genes and all chemokine receptors known for rainbow trout. These data contribute to a better understanding of the early immune mechanisms elicited by DNA vaccination in fish.

\section{Materials and methods}

\subsection{VHSV DNA vaccine}

The VHSV DNA vaccine used in this study, designated pVHSV, has been previously described $[15,23]$. The empty pcDNA3 plasmid was used as a control.

\subsection{Fish}

Rainbow trout ( 0 . mykiss) were maintained at $11-16^{\circ} \mathrm{C}$ in a re-circulating water system and fed with a commercial diet (Skretting). Prior to any experimental procedures, fish were acclimatized to laboratory conditions. All the experiments described comply with the Guidelines of the European Union Council (2010/63/EU) for the use of laboratory animals and have been approved by the corresponding local Ethics Committees.

\subsection{Transcriptional studies in muscle}

For the transcriptional studies, fish were injected i.m. with $1 \mu \mathrm{g}$ of pVHSV plasmid, $1 \mu \mathrm{g}$ of pcDNA3 in PBS $(50 \mu \mathrm{l})$ or the same volume of PBS in the epaxial muscle below the dorsal fin by use of a $27 \mathrm{G}$ needle. In some experiments, VHSV virus, propagated as previously described [24], was heat-inactivated $\left(56^{\circ} \mathrm{C}\right.$ for $\left.30 \mathrm{~min}\right)$ and injected i.m. in parallel to the DNA vaccine $\left(1 \times 10^{6} \mathrm{TCID}_{50}\right.$ per fish). At days 3,6 and 14 post-vaccination, six fish from the different groups were killed and the muscle area surrounding the injection site sampled and placed in Trizol (Invitrogen) for RNA isolation following the manufacturer's instructions.

RNAs were treated with DNAse I to remove genomic DNA that might interfere with the PCR reactions. An amount of $1 \mu \mathrm{g}$ of RNA was used to obtain cDNA in each sample using the Superscript III reverse transcriptase (Invitrogen) and oligo (dT) ${ }_{12-18}$ following the manufacturer's instructions.

To evaluate the levels of transcription of different immune genes, real-time PCR was performed with a LightCycler $^{\circledR} 480$ System (Roche) using FastStart SYBR Green Master mix (Roche) following the manufacturer's instructions. Reaction mixtures were incubated for $10 \mathrm{~min}$ at $95^{\circ} \mathrm{C}$, followed by 40 amplification cycles ( $30 \mathrm{~s}$ at $95^{\circ} \mathrm{C}$ and $1 \mathrm{~min}$ at $60^{\circ} \mathrm{C}$ ). For each gene, expression was normalized to that of elongation factor $1 \alpha(\mathrm{EF}-1 \alpha)$ expression in each sample and expressed as $2^{-\Delta C t}$ as described previously [25].
Primers used were already optimized [25,26] and are shown in Supplementary Fig. 1.

To verify that IgM and IgT transcripts quantified were not sterile Ig transcripts, PCRs were performed using a forward primer specific for a subgroup or a set of IGHV genes in combination with a reverse primer $\mathrm{C} \mu$ or $\mathrm{C} \tau$ specific for IGHM or IGHT genes, in a pooled cDNA sample from each experimental group as previously described [20] (Supplementary Fig. 1).

\subsection{Immunocytochemistry}

To evaluate the infiltration through immunohistochemistry, fingerlings of $3-4 \mathrm{~g}$ were anaesthetised in $0.01 \%$ benzocaine and injected with $20 \mu \mathrm{g}$ of pVHSV or empty plasmid dissolved in $0.9 \%$ $\mathrm{NaCl}$ or with the same volume of $0.9 \% \mathrm{NaCl}$ in the muscle. Muscle sections obtained from control and vaccinated fish $(N=3)$ at day 7 post-immunization were subjected to an indirect immunocytochemical method for detection of trout IgM and IgT using monoclonal antibodies F1-18 and F1-15 kindly donated by Dr. Kurt Buchmann and Dr. Karsten Skjoedt as previously described [27,28]. The specificity of the reactions was determined by omitting the primary antibodies.

\subsection{Isolation and characterization of infiltrated B cells from muscle after DNA injection}

To isolate and further characterize the cells infiltrated in the muscle after DNA vaccination, fish weighing approx. $150 \mathrm{~g}$ received six i.m. injections of $40 \mu \mathrm{l}(1 \mathrm{mg} / \mathrm{ml})$ of the VHSV DNA vaccine or the empty vector as control. Another group was injected with the same volume of complete Freund's adjuvant (Sigma-Aldrich). Injection needles were placed approx. $1 \mathrm{~cm}$ deep into the dorsal muscle. At the day of sampling, fish were killed and muscle tissue around the injection site (approx. $1 \times 1 \times 1 \mathrm{~cm}$ ) excised into ice cold medium (Iscove's DMEM/Ham's F12; Gibco). The tissue was cut into small pieces and trypsin solution added at a final ratio of $10 \%$ $(\mathrm{v} / \mathrm{v})$. After $1 \mathrm{~h}$ of incubation at room temperature, the suspension was filtered through a nylon mesh $(100 \mu \mathrm{m})$, layered onto a twostep Percoll gradient $(1.035 \mathrm{~g} / \mathrm{ml}$ and $1.08 \mathrm{~g} / \mathrm{ml})$ and centrifuged for $40 \mathrm{~min}$ at $650 \times \mathrm{g}$ at $4{ }^{\circ} \mathrm{C}$. The interphase was collected and washed twice.

Infiltrating cells $\left(1 \times 10^{6}\right.$ cells $\left./ \mathrm{ml}\right)$ were stained using primary antibodies against either IgM (mab 4C10; [29]), CD8 $\alpha$ [30] and IgT [19]. IgM and $C D 8 \alpha$ staining was carried out simultaneously using TRICOLOR anti-mouse Ig (Caltag) and FITC anti-rat IgG ( H + L) (Jackson ImmunoResearch) conjugates, respectively, while IgT $^{+}$cells were single-stained using an Alexa488 anti-mouse-IgG (Caltag) conjugate.

\subsection{Production of recombinant CK5B and CK6}

To produce recombinant trout CK5B and CK6 in Escherichia coli, the cDNA sequences encoding the mature chemokines were amplified and cloned into a modified pET vector (Novagen) using specific primers (Supplementary Fig. S1). After sequence confirmation, the chemokine expressing plasmids were transformed into $E$. coli strain BL21 Star (DE3)pLysS (Invitrogen). The recombinant proteins were produced as described previously [31,32].

\subsection{Chemotactic assays with recombinant $C K 5 B$ and $C K 6$}

The capacity of rainbow trout recombinant CK5B and CK6 to attract leukocytes from different sources was evaluated. For this, leukocytes from spleen, blood and head kidney were isolated from naïve fish following the method previously described [33]. Cells 

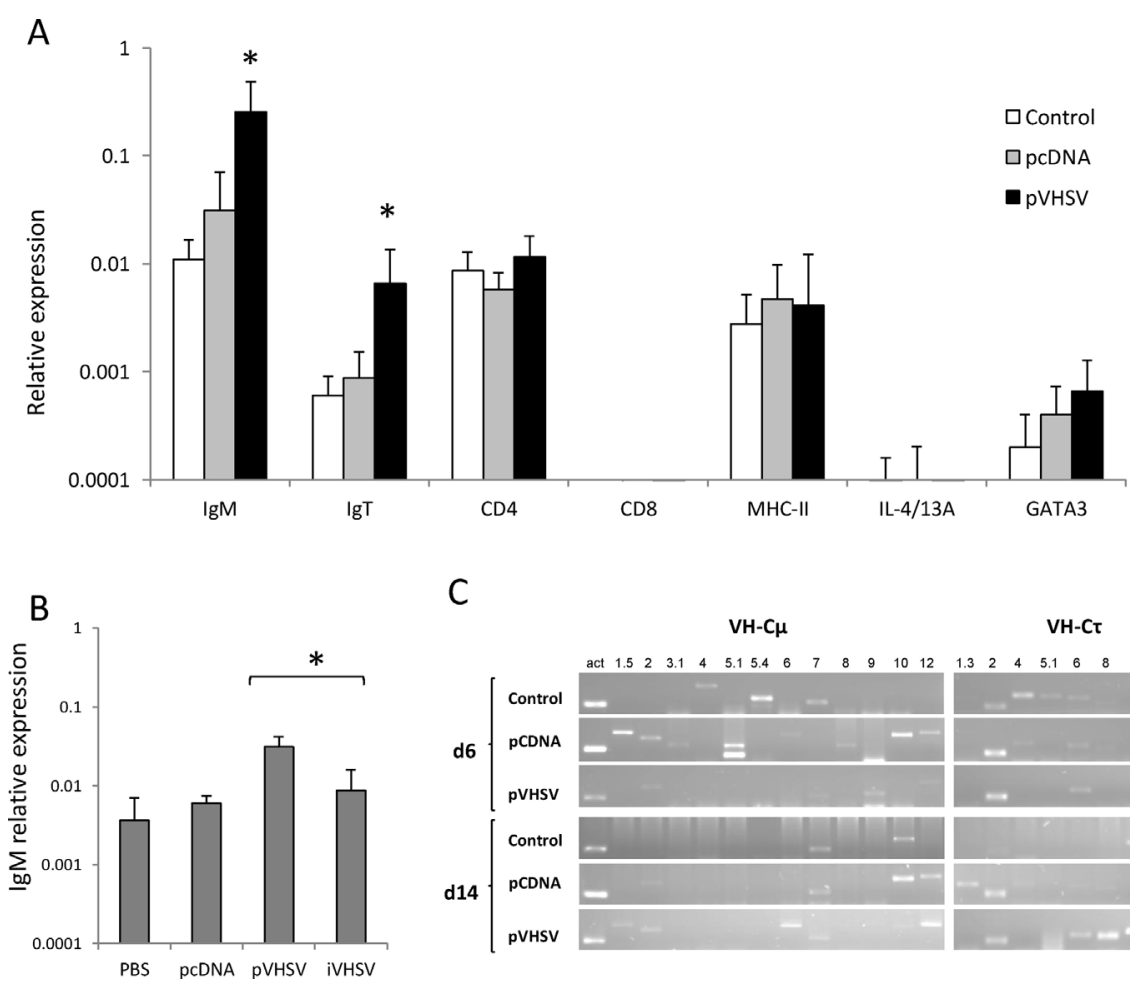

C

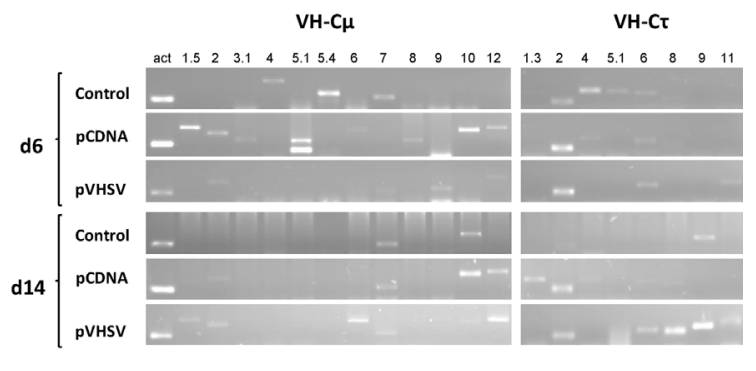

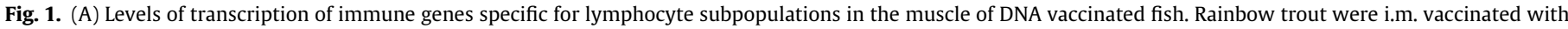

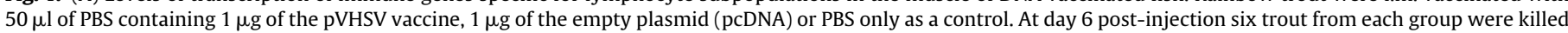

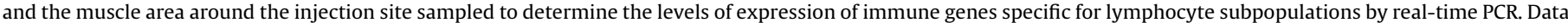

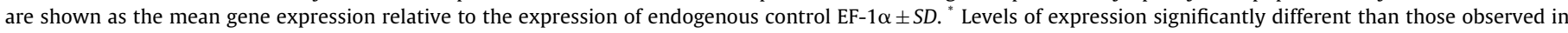

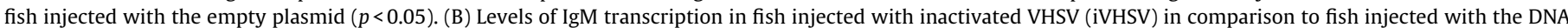

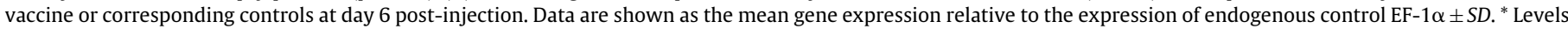

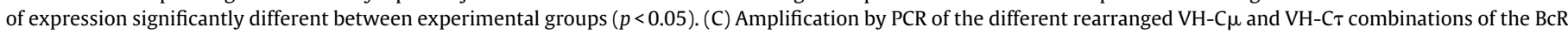

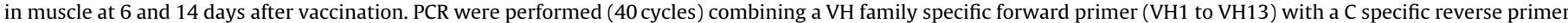
$(\mathrm{C} \mu$ or $\mathrm{C} \tau)$. Only combinations amplified in at least one group are shown. $\beta$-actin (act, 30 cycles) was used as housekeeping gene.

were resuspended in L-15 with $2 \%$ FCS at a concentration of $1 \times 10^{6}$ cells $/ \mathrm{ml}$.

The chemotaxis assays were performed in chemotaxis chambers introduced in 24-well plates (Costar-Corning Life Sciences). Six hundred $\mu$ l of different dilutions of CK5B or CK6 in culture medium were placed at the bottom of the wells, while $100 \mu \mathrm{l}$ of the different leukocyte cell suspensions were loaded to the upper chamber. After $2 \mathrm{~h}$ at $20^{\circ} \mathrm{C}$, the number of cells that had migrated to the bottom of the wells was quantified by flow cytometry as previously described [25].

\subsection{In vivo chemotactic assays using CK5B and CK6 expression plasmids}

Plasmids coding for rainbow trout CK5B and CK6 previously obtained [34] were used to confirm the chemotactic capacity of these chemokines. Fish were injected i.m. with $1 \mu \mathrm{g}$ of either pCK5B, pCK6 or the pcDNA3.1 control plasmid (in $50 \mu$ l of PBS). At day 6 post-injection, three fish per group were sampled to evaluate the levels of infiltration through histological techniques.

\subsection{Statistics}

Data handling, analyses and graphic representation was performed using Microsoft Office Excel 2010. Statistically significant differences were determined using a Mann-Whitney $U$ test or a one-way ANOVA $(p<0.05)$.

\section{Results}

\subsection{B cells are a major leukocyte population infiltrated in the muscle of vaccinated fish}

Real time PCR analysis revealed a significant increase in transcription levels of both IGHM (IgM) and IGHT (IgT) in vaccinated compared to mock-vaccinated fish from day 6 post-vaccination (Fig. 1A). Although CD4, MHC-II and GATA-3 transcription was detected in the muscle, the levels of transcription were not significantly different between the different experimental groups. CD8 and IL-4/13A transcription remained mostly undetected in all groups. The up-regulation of IGHM transcription in response to pVHSV was not observed when the inactivated virus was i.m. injected (Fig. 1B). The levels of IGHM and IGHT remained elevated at day 14 post-vaccination (data not shown). Several different VH$\mathrm{C} \mu$ and $\mathrm{VH}-\mathrm{C} \tau$ transcripts were retrieved by PCR from the muscle at days 6 and 14 (Fig. 1C), indicating the presence of rearranged B cell receptor mRNAs in the infiltrated cells. We found a higher number of different $\mathrm{VH}-\mathrm{C} \mu$ and $\mathrm{VH}-\mathrm{C} \tau$ amplifications for $\mathrm{pVHSV}$ samples at day 14 in comparison to control and pcDNA samples.

Immunohistochemistry analyses were also conducted to detect $\operatorname{IgM}^{+}$and $\operatorname{IgT}^{+}$cells in the muscle. In concordance with the transcriptional studies and in contrast to the situation in higher vertebrates $[21,22]$, high levels of both IgM and IgT were found at the injection site (Fig. 2).

To further verify that B cells were actually present in the muscle, we optimized a protocol for the isolation of infiltrating cells. 


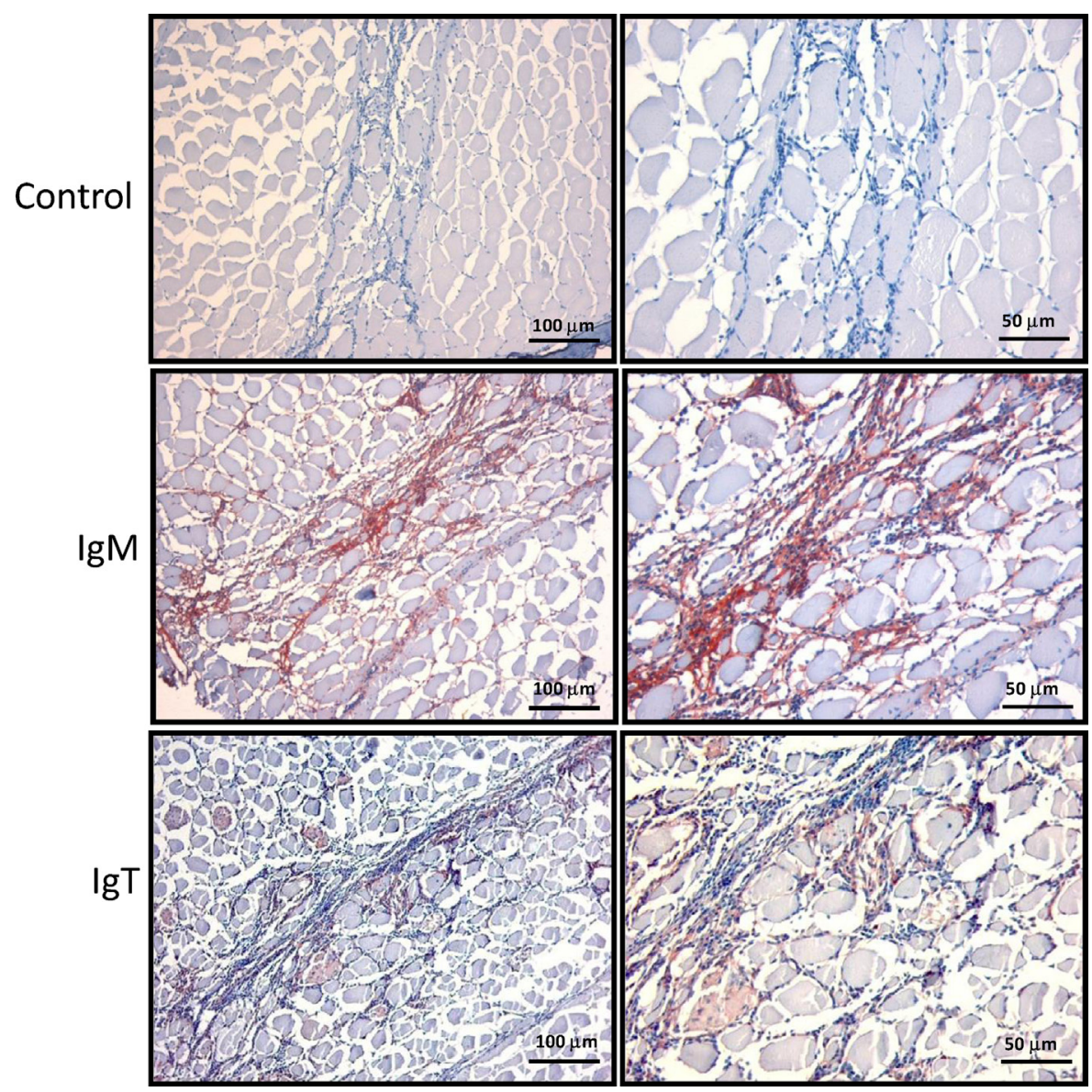

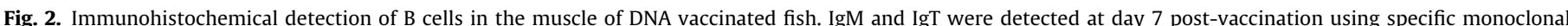

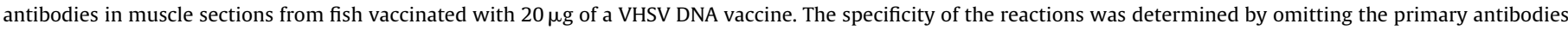
(isotype control). Two micrographs are shown in each case with different magnifications ( $20 \times$ and $40 \mathrm{x})$. Bars correspond to $100 \mu \mathrm{m}$ and $50 \mu \mathrm{m}$, respectively.

Although some infiltrating cells were detected in response to the empty plasmid, the number of cells in vaccinated fish was higher. Infiltrated cells collected 6 days after i.m. VHSV DNA vaccination mostly had a profile of lymphocyte-type cells, with small size and low complexity (Fig. 3A). Within this population, IgM $^{+}$cells were a predominant cell type (Fig. $3 \mathrm{~A}$ ), with a lower percentage of $\operatorname{IgT}^{+}$ cells and $\mathrm{CD}^{+}$cells present. When CFA was injected instead of the DNA vaccine, the profile of the infiltrated cells was more heterogeneous, including a large number of granulocyte/monocyte-type cells with bigger size and higher granularity (Fig. 3B). Among the gated lymphocyte-type cells, we again detected a high percentage of $\operatorname{IgM}^{+}$cells in addition to $\mathrm{IgT}^{+}$and $\mathrm{CD}^{+}$cells. When fish were sampled at a later time post-vaccination (day 17), infiltrating cells could not be recovered from the group injected with the empty plasmid but only from the groups injected with the VHSV vaccine or CFA. The experiment was repeated once and similar results were observed. These results confirm that rainbow trout $B$ cells are recruited to the vaccine injection site and reveal that both $\operatorname{IgM}^{+}$and $\operatorname{IgT}^{+}$cells have the capacity to infiltrate the muscle.

\subsection{Chemokine and chemokine receptor transcription at the injection site}

We evaluated the levels of transcription of different chemokines in vaccinated and mock-vaccinated fish, studying a wide selection of rainbow trout chemokines that include representatives of the chemokine clades previously established $[35,36]$. At day 3 postvaccination, CK1, CK3, CK5B, CK6, CK9, CK10, CK11, CK12, CXCL8_L1, CXCL_F1 and CXCL11_L1 were transcribed in the muscle (Fig. 4A), but CXCL11_L1 was the only chemokine for which transcription was significantly higher in vaccinated animals. At day 6 postvaccination, CXCL11_L1 levels were similar in all groups, whereas CK5B and CK6 mRNA levels were significantly elevated (Fig. 4B). At day 14 post-vaccination, no significant differences were apparent between the groups (Fig. 4C).

The levels of transcription of trout chemokine receptors in the muscle of vaccinated and mock-vaccinated fish were studied at day 6 post-injection. Although CCR6, CCR9B and CXCR3A transcription was almost undetected in all samples, transcription of CCR7, CCR9, CCR13, CXCR1, CXCR3B and CXCR4 was found in muscle (Fig. 5). However, only the transcription of CXCR3B was significantly higher in vaccinated fish.

\subsection{Trout CK5B and CK6 exhibit chemoattractant capacity}

Since the chemoattractant capacity of trout CK5B and CK6 had not been studied, we produced these chemokines as recombinant proteins and purified them under denaturing conditions (Supplementary Fig. 2). Recombinant CK5B and CK6 were used in chemotaxis assays in vitro using blood, spleen and head kidney leukocytes. Blood and head kidney leukocytes were significantly attracted by recombinant $\mathrm{CK} 5 \mathrm{~B}$ at a concentration of $1 \mathrm{ng} / \mathrm{ml}$, while splenocytes did not respond to CK5B (Fig. 6A). In the case of CK6, only head kidney leukocytes were significantly attracted by this chemokine (Fig. 6B). These results confirm that CK5B and CK6 both have chemotactic capacities.

To further support the hypothesis that the up-regulation of CK5B and CK6 transcription observed at day 6 post-vaccination 

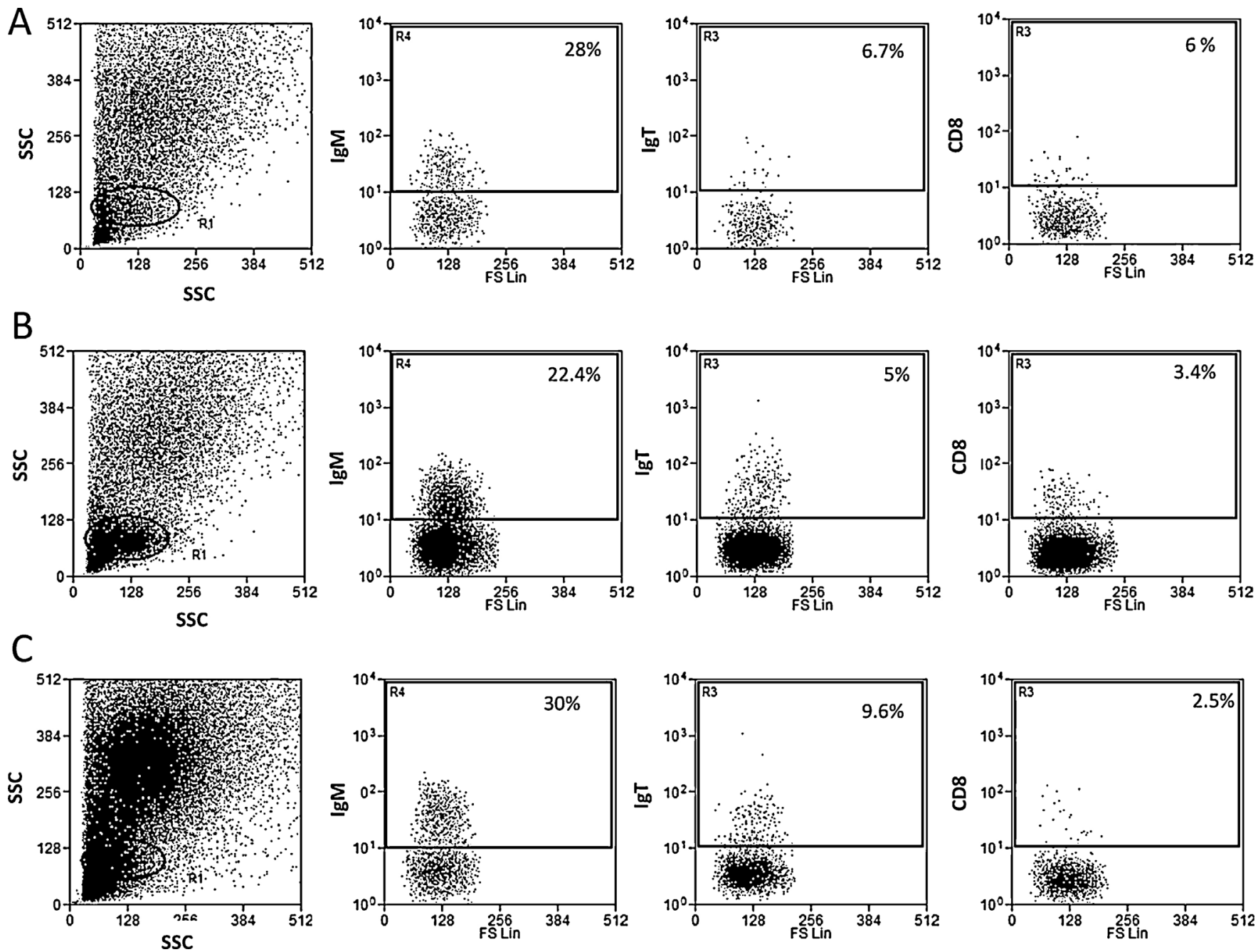

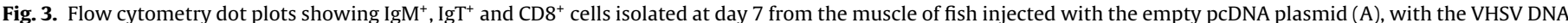

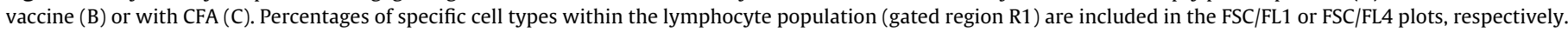
The data shown correspond to the pooled leukocytes isolated from four fish each. Percentages refer to the positive cells within the lymphocyte region.

was contributing to the recruitment of B cells to the muscle, CK5B and CK6 coding plasmids were injected i.m. and the infiltration of $\operatorname{IgM}^{+}$and $\operatorname{IgT}^{+}$cells studied through immunohistochemistry. The infiltration of $\operatorname{IgM}^{+}$cells in response to both pCK5B and pCK6 was visible through immunohistochemistry (Fig. 6C and D). Conversely, we could never detect a significant infiltration of $\operatorname{IgT}^{+}$cells.

\section{Discussion}

Although different studies have analysed different aspects of the immunogenicity of DNA vaccines in fish, none have addressed the early recruitment of leukocytes to the muscle, or analysed which chemokines and chemokine receptors could be responsible for such a mobilization. In mammals, it is well known that myocytes do not express MHC class II nor co-stimulatory molecules and therefore the priming of $\mathrm{T}$ cells occurs through the recruitment and activation of professional antigen presenting cells (APCs), mainly dendritic cells (DCs) $[37,38]$ and not B cells, which are only marginally activated in response to vaccination [38]. In the current work, we have established that both $\operatorname{IgM}^{+}$and $\operatorname{IgT}^{+} \mathrm{B}$ lymphocytes migrate in large numbers to the area of antigen expression after injection of a VHSV DNA vaccine. In most teleost species, the presence of professional APCs has not been clearly established [39] and no surface markers are available for fish DCs. In addition to DCs, B cells are also considered highly efficient APCs in mammals [40], and therefore it is possible that fish B cells mobilized to the muscle after DNA vaccination could play a role in antigen presentation locally in addition to other APCs, taking into account the absence of lymph nodes in teleost fish. Furthermore, the very high constitutive levels of $\mathrm{CD} 80 / 86$ in trout $\operatorname{IgM}^{+}$cells reported by Zhang et al. [41], led the authors to speculate that fish $\operatorname{IgM}^{+}$B cells could be major APCs in fish. We also isolated some $\mathrm{CD}^{+}$cells from the vaccinated muscle, even though no CD8 transcripts were detected. On the other hand, we detected CD4 transcripts but we could not analyse the presence of $\mathrm{CD} 4^{+}$cells through flow cytometry because there is no antibody available to date. Interestingly, our results reveal a novel non-mucosal role for $\operatorname{IgT}^{+}$cells, as also observed by Castro et al. [20]. In any case, more work should be performed to establish the role of all these cells mobilized to the muscle in the immunity to DNA vaccination.

Notably, this massive B infiltration into the muscle was not observed when fish were injected with inactivated virus instead of the DNA vaccine. Although this could suggest that the expression of the VHSV glycoprotein in the cellular membrane of myocytes contributes to a greater immune response, it might be possible that it is a consequence of a higher amount of $G$ protein available due to the strong and prolonged production of $G$ protein observed after DNA vaccination [15]. This higher amount of $G$ protein may trigger 

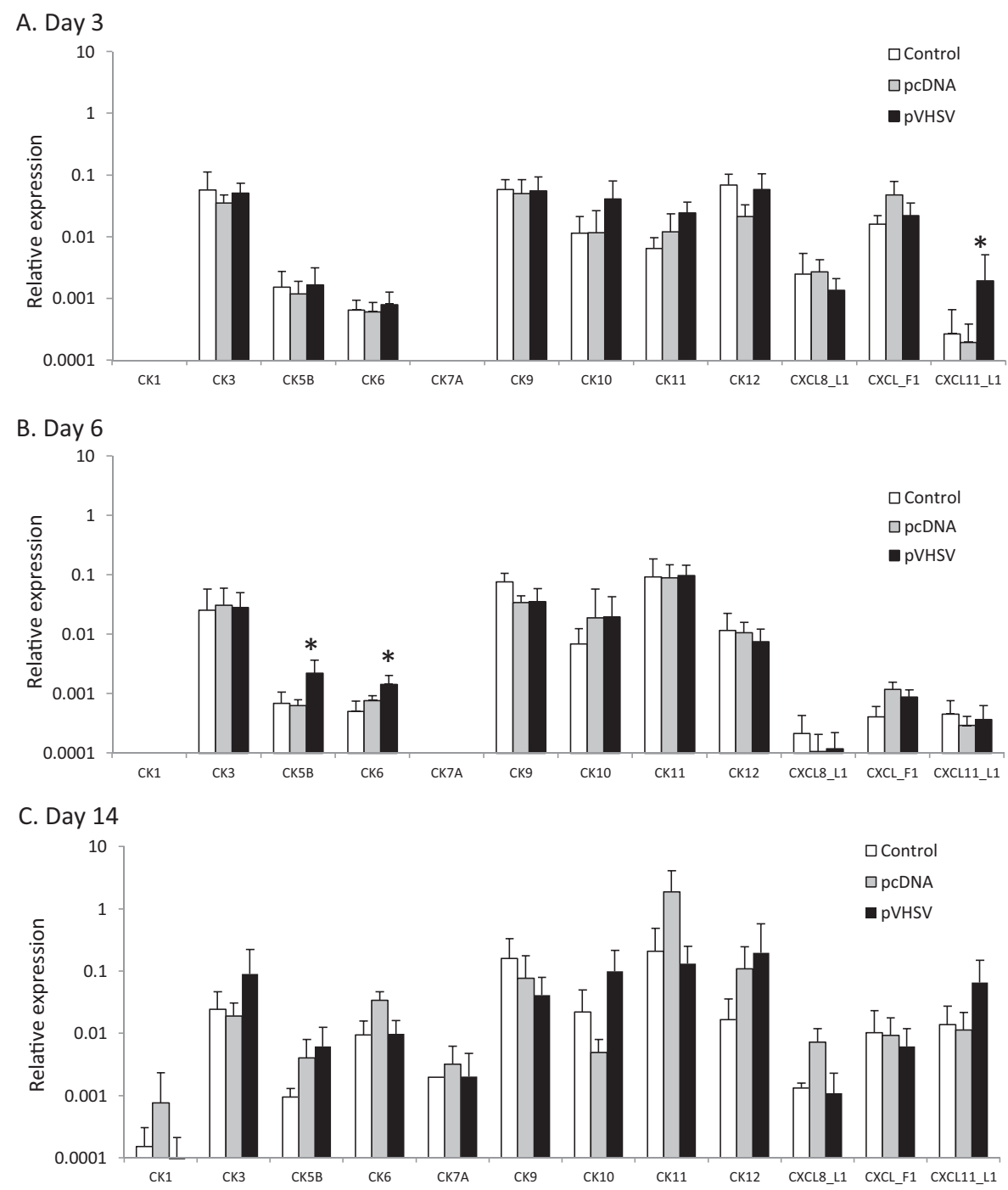

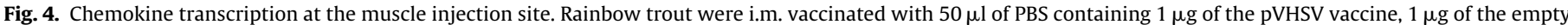

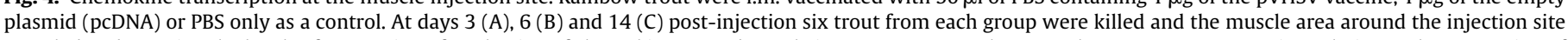

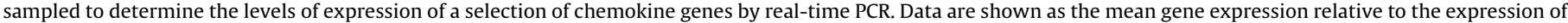
endogenous control EF- $1 \alpha \pm S D .{ }^{*}$ Levels of expression significantly different to those observed in fish injected with the empty plasmid ( $p<0.05$ ).

not only a quantitatively different response but also one of a different nature. Previous reports have shown that the $G$ protein from the rhabdovirus vesicular stomatitis virus (VSV) induces a T-dependent response when inoculated at low doses, but a T-independent response when higher doses are administered [42]. In fact, the VSV G protein has been shown to be an excellent T-independent antigen [43], as occurs with other viral proteins [44]. Interestingly, one of the most effective DNA vaccines tested in mice has been a glycoprotein-encoding DNA vaccine against rabies, another rhabdovirus [45]. Thus, it might be relevant to evaluate whether the responses elicited by all rhabdoviral DNA vaccines have important T-independent components that render them especially effective.

To understand the mechanism by which leukocytes are recruited to the muscle, we studied the levels of transcription of trout chemokines and chemokine receptors. The transcription of CXCL11_L1, a chemokine closely related to mammalian CXCL10 [36], was up-regulated in the muscle of vaccinated fish at day 3 post-injection. Although at this early stage, there is still a considerable infiltration of leukocytes as a result of tissue damage, it might be interesting in the future to study whether CXCL11_L1 is also capable of recruiting $B$ cells as reported in some mammalian species [46], despite the fact that previous evidence in trout suggests that

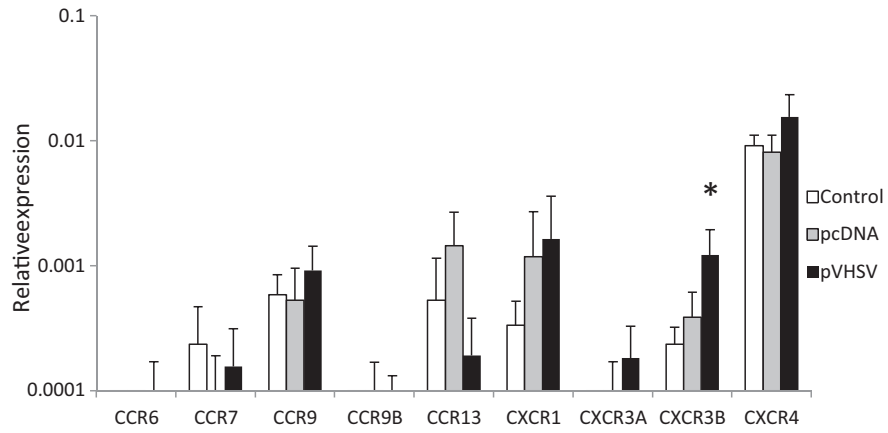

Fig. 5. Transcription of chemokine receptors at the muscle injection site. Rainbow trout were i.m. vaccinated as described in the Fig. 4 legend. At day 6 post-injection six trout from each group were killed and the muscle area around the injection site sampled to determine the levels of expression of rainbow trout chemokine receptor genes by real-time PCR. Data are shown as the mean gene expression relative to the expression of endogenous control EF- $1 \alpha \pm S D$. * Levels of expression significantly different to those observed in fish injected with the empty plasmid $(p<0.05)$. 

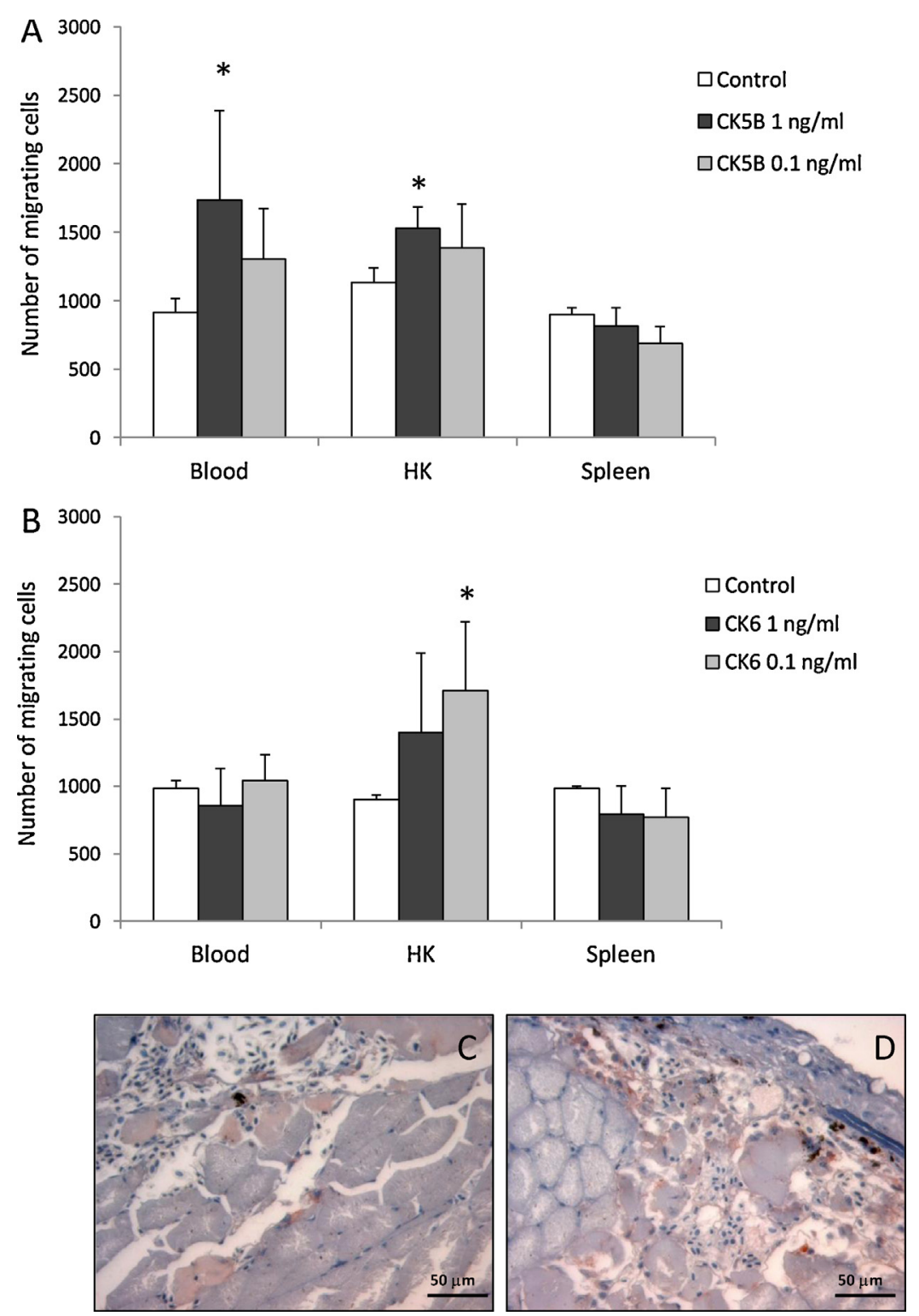

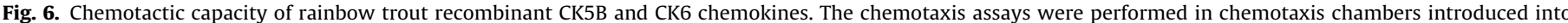

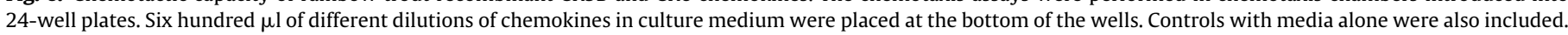

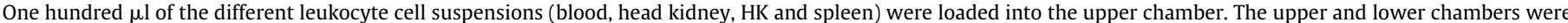

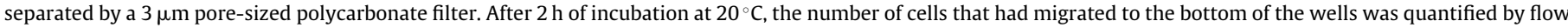

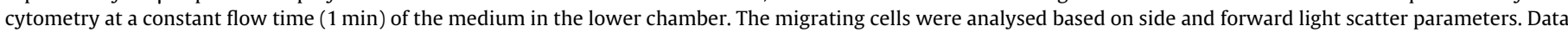

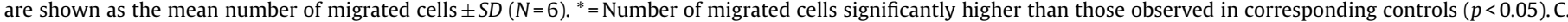
Detection of IgM in muscle of trout injected with pCK5B. D. Detection of IgM in muscle of trout injected with pCK6.

CXCL11_L1 is mainly chemoattractant for macrophages and CD4 ${ }^{+}$ cells [36]. CXCL10 is a gamma interferon inducible CXC chemokine, as is CXCL9 and CXCL11, all of them sharing the same receptor, CXCR3, which in trout has two different isoforms [47]. Interestingly, we have observed a significant up-regulation of CXCR3B in vaccinated animals that suggests that this chemokine-chemokine receptor association is maintained in teleost. On the other hand, transfection of human primary muscle cells with a DNA vaccine provoked an increased CXCL10 transcription [22]. At day 6 postvaccination, a significant up-regulation of CK5B and CK6 was found in the vaccinated muscle. According to the classification of CC chemokines established by Peatman and Liu [35], rainbow trout CK5B groups with mammalian CCL5 genes. Although CCL5 is associated mostly with the recruitment of Thelper cells [48], it was also up-regulated in the central nervous system together with a significant B cell infiltration [46] and CCR3, one of its possible receptors, has been detected on bone marrow plasma cells [49]. Surprisingly, CCL5 was also up-regulated in human primary muscle cells transfected with a DNA vaccine, suggesting some conservation in the elicited mechanisms in mammals and fish [22]. On the other hand, CK6 has been ascribed to the CCL17/22 group. In mammals, CD40stimulated B cells secrete CCL17 and CCL22, attracting memory $\mathrm{CD}^{+} \mathrm{T}$ cells to an antigen rich environment [50]. In this study, we have demonstrated the chemoattractant capacity of CK5B and CK6. Furthermore, plasmids encoding trout chemokines provoked an infiltration of IgM $^{+}$cells when injected into the muscle of rainbow trout. Taken together, these data suggest that CK5B and CK6 contribute to the recruitment of $\mathrm{B}$ cells into the muscle.

In conclusion, DNA vaccination against VHSV in rainbow trout induced a large infiltration of both $\operatorname{IgM}^{+}$and $\mathrm{IgT}^{+}$cells $\mathrm{B}$ cells. This infiltration was a characteristic feature in response to DNA vaccination which was neither observed after i.m. injection of inactivated 
virus nor of CFA and was accompanied with an up-regulation of CXCL11_L1, CK5B, CK6 and CXCR3B genes. We have also established the chemotactic capacity of CK5B and CK6, strongly suggesting that the induced chemokines contribute to the observed leukocyte recruitment to the muscle.

\section{Acknowledgements}

This work was supported by the European Research Council (ERC Starting Grant 2011280469 ) and by the European Commission under the 7th Framework Programme for Research and Technological Development (FP7) of the European Union (Grant Agreement 311993 TARGETFISH). Support was also received from the Danish Council for Strategic Research, grant 2101-08-0017 Dafinet. The authors want to thank Oriol Sunyer for providing the anti-IgT antibody used in flow cytometry. Kurt Buchmann and Karsten Skjoedt are also acknowledged for providing the monoclonal antibodies against IgM and IgT used in immunohistochemistry. We also thank Pierre Boudinot for the critical reading of the manuscript.

Conflict of interest statement: Authors have no conflict of interest.

\section{Appendix A. Supplementary data}

Supplementary data associated with this article can be found, in the online version, at http://dx.doi.org/10.1016/j.vaccine.2013. 11.062 .

\section{References}

[1] Lorenzen N, Lorenzen E, Einer-Jensen K, LaPatra SE. Immunity induced shortly after DNA vaccination of rainbow trout against rhabdoviruses protects against heterologous virus but not against bacterial pathogens. Dev Comp Immunol 2002;26:173-9

[2] Lorenzen N, Lorenzen E, Einer-Jensen K, Heppell J, Wu T, Davis H. Protective immunity to VHS in rainbow trout (Oncorhynchus mykiss Walbaum) following DNA vaccination. Fish Shellfish Immunol 1998;8:261-70.

[3] Takano T, Iwahori A, Hirono I, Aoki T. Development of a DNA vaccine against hirame rhabdovirus and analysis of the expression of immune-related genes after vaccination. Fish Shellfish Immunol 2004;17:367-74.

[4] Emmenegger EJ, Kurath G. DNA vaccine protects ornamental koi (Cyprinus carpio koi) against North American spring viremia of carp virus. Vaccine 2008:26:6415-21.

[5] de las Heras AI, Rodriguez Saint-Jean S, Perez-Prieto SI. Immunogenic and protective effects of an oral DNA vaccine against infectious pancreatic necrosis virus in fish. Fish Shellfish Immunol 2010;28:562-70.

[6] Cuesta A, Chaves-Pozo E, de Las Heras AI, Saint-Jean SR, Perez-Prieto S. Tafalla C. An active DNA vaccine against infectious pancreatic necrosis virus (IPNV) with a different mode of action than fish rhabdovirus DNA vaccines. Vaccine 2010;28:3291-300.

[7] Zhang M, Hu YH, Xiao ZZ, Sun Y, Sun L. Construction and analysis of experimental DNA vaccines against megalocytivirus. Fish Shellfish Immunol 2012;33:1192-8

[8] LaPatra SE, Corbeil S, Jones GR, Shewmaker WD, Lorenzen N, Anderson ED, et al. Protection of rainbow trout against infectious hematopoietic necrosis virus four days after specific or semi-specific DNA vaccination. Vaccine 2001;19:4011-9.

[9] McLauchlan PE, Collet B, Ingerslev E, Secombes CJ, Lorenzen N, Ellis AE. DNA vaccination against viral haemorrhagic septicaemia (VHS) in rainbow trout: size, dose, route of injection and duration of protection-early protection correlates with Mx expression. Fish Shellfish Immunol 2003;15:39-50.

[10] Salonius K, Simard N, Harland R, Ulmer JB. The road to licensure of a DNA vaccine. Curr Opin Invest Drugs 2007;8:635-41.

[11] Utke K, Kock H, Schuetze H, Bergmann SM, Lorenzen N, Einer-Jensen K, et al. Cell-mediated immune responses in rainbow trout after DNA immunization against the viral hemorrhagic septicemia virus. Dev Comp Immunol 2008;32:239-52.

[12] Purcell MK, Kurath G, Garver KA, Herwig RP, Winton JR. Quantitative expression profiling of imune response genes in rainbow trout following infectious haematopoietic necrosis virus (IHNV) infection or DNA vaccination. Fish Shellfish Immunol 2004;17:447-62.

[13] Cuesta A, Tafalla C. Transcription of immune genes upon challenge with viral hemorrhagic septicemia virus (VHSV) in DNA vaccinated rainbow trout (Oncorhynchus mykiss). Vaccine 2009;27:280-9.

[14] Purcell MK, Nichols KM, Winton JR, Kurath G, Thorgaard GH, Wheeler P, et al. Comprehensive gene expression profiling following DNA vaccination of rainbow trout against infectious hematopoietic necrosis virus. Mol Immunol 2006;43:2089-106.
[15] Lorenzen E, Lorenzen N, Einer-Jensen K, Brudeseth B, Evensen O. Time course study of in situ expression of antigens following DNA-vaccination against VHS in rainbow trout (Oncorhynchus mykiss Walbaum) fry. Fish Shellfish Immuno 2005;19:27-41.

[16] Warr GW, De Luca D, Griffin BR. Membrane immunoglobulin is present on thymic and splenic lymphocytes of the trout Salmo gairdneri. J Immunol 1979;123:910-7.

[17] Hordvik I, Thevarajan J, Samdal I, Bastani N, Krossøy B. Molecular cloning and phylogenetic analysis of the Atlantic salmon immunoglobulin D gene. Scand J Immunol 1999;50:202-10.

[18] Hansen JD, Landis ED, Phillips RB. Discovery of a unique Ig heavy-chain isotype (IgT) in rainbow trout: Implications for a distinctive B cell developmental pathway in teleost fish. PNAS 2005;102:6919-24.

[19] Zhang YA, Salinas I, Li J, Parra D, Bjork S, Xu Z, et al. IgT, a primitive immunoglobulin class specialized in mucosal immunity. Nat Immunol 2010;11: 827-35.

[20] Castro R, Jouneau L, Pham HP, Bouchez O, Giudicelli V, Lefranc MP, et al. Teleost fish mount complex clonal IgM and IgT responses in spleen upon systemic viral infection. PLoS Pathog 2013;9:e1003098.

[21] Barouch DH, Santra S, Tenner-Racz K, Racz P, Kuroda MJ, Schmitz JE, et al. Potent $\mathrm{CD}^{+} \mathrm{T}$ cell responses elicited by a bicistronic HIV-1 DNA vaccine expressing gp120 and GM-CSF. J Immunol 2002;168:562-8.

[22] Shirota H, Petrenko L, Hong C, Klinman DM. Potential of transfected muscle cells to contribute to DNA vaccine immunogenicity. J Immunol 2007;179: 329-36.

[23] Lorenzen N, Lorenzen E, Einer-Jensen K, Heppell J, Wu T, Davis H. Protective immunity to VHS in rainbow trout (Oncorhynchus mykiss Walbaum) following DNA vaccination. Fish Shellfish Immunol 1998;8:261-70.

[24] Ordas MC, Cuesta A, Mercado L, Bols NC, Tafalla C. Viral hemorrhagic septicaemia virus (VHSV) up-regulates the cytotoxic activity and the perforin/granzyme pathway in the rainbow trout RTS11 cell line. Fish Shellfish Immunol 2011:31:252-9.

[25] Montero J, Garcia J, Ordas MC, Casanova I, Gonzalez A, Villena A, et al. Specific regulation of the chemokine response to viral hemorrhagic septicemia virus at the entry site. J Virol 2011;85:4046-56.

[26] Martinez-Alonso S, Vakharia VN, Saint-Jean SR, Perez-Prieto S, Tafalla C. Immune responses elicited in rainbow trout through the administration of infectious pancreatic necrosis virus-like particles. Dev Comp Immunol 2012:36:378-84

[27] Olsen MM, Kania PW, Heinecke RD, Skjoedt K, Rasmussen KJ, Buchmann K. Cellular and humoral factors involved in the response of rainbow trout gills to Ichthyophthirius multifiliis infections: molecular and immunohistochemical studies. Fish Shellfish Immunol 2011;30:859-69.

[28] von Gersdorff Jorgensen L, Heinecke RD, Skjodt K, Rasmussen KJ, Buchmann $\mathrm{K}$. Experimental evidence for direct in situ binding of IgM and IgT to early trophonts of Ichthyophthirius multifiliis (Fouquet) in the gills of rainbow trout, Oncorhynchus mykiss (Walbaum). J Fish Diseases 2011;34:749-55.

[29] Thuvander A, Fossum C, Lorenzen N. Monoclonal antibodies to salmonid immunoglobulin: characterization and applicability in immunoassays. Dev Comp Immunol 1990;14:415-23.

[30] Takizawa F, Dijkstra JM, Kotterba P, Korytar T, Kock H, Kollner B, et al. The expression of CD8alpha discriminates distinct T cell subsets in teleost fish. Dev Comp Immunol 2011;35:752-63.

[31] Costa MM, Maehr T, Diaz-Rosales P, Secombes CJ, Wang T. Bioactivity studies of rainbow trout (Oncorhynchus mykiss) interleukin-6: effects on macrophage growth and antimicrobial peptide gene expression. Mol Immunol 2011;48:1903-16

[32] Wang T, Diaz-Rosales P, Costa MM, Campbell S, Snow M, Collet B, et al. Functional characterization of a nonmammalian IL-21: rainbow trout Oncorhynchus mykiss IL-21 upregulates the expression of the Th cell signature cytokines IFNgamma, IL-10, and IL-22. J Immunol 2011;186:708-21.

[33] Graham S, Secombes CJ. The production of macrophage-activating factor from rainbow trout Salmo gairdneri leucocytes. Immunology 1988;65:293-7.

[34] Montero J, Chaves-Pozo E, Cuesta A, Tafalla C. Immune effects observed after the injection of plasmids coding for rainbow trout (Oncorhynchus mykiss) CK5B, CK6 and CK7A chemokines demonstrate their immunomodulatory capacity and reveal CK6 as a major interferon inducer. Dev Comp Immunol 2009;33:1137-45

[35] Peatman E, Liu Z. Evolution of CC chemokines in teleost fish: a case study in gene duplication and implications for immune diversity. Immunogenetics 2007:59:613-23.

[36] Chen J, Xu Q, Wang T, Collet B, Corripio-Miyar Y, Bird S, et al. Phylogenetic analysis of vertebrate $\mathrm{CXC}$ chemokines reveals novel lineage specific groups in teleost fish. Dev Comp Immunol 2013:41:137-52.

[37] Fu TM, Ulmer JB, Caulfield MJ, Deck RR, Friedman A, Wang S, et al. Priming of cytotoxic T lymphocytes by DNA vaccines: requirement for professional antigen presenting cells and evidence for antigen transfer from myocytes. Mol Med 1997:3:362-71.

[38] Casares S, Inaba K, Brumeanu TD, Steinman RM, Bona CA. Antigen presentation by dendritic cells after immunization with DNA encoding a major histocompatibility complex class II-restricted viral epitope. J Exp Med 1997;186: 1481-6.

[39] Bassity E, Clark TG. Functional identification of dendritic cells in the teleost model, rainbow trout (Oncorhynchus mykiss). PLoS One 2012;7:e33196.

[40] Rodriguez-Pinto D. B cells as antigen presenting cells. Cell Immunol 2005;238:67-75 
[41] Zhang YA, Hikima J, Li J, LaPatra SE, Luo YP, Sunyer JO. Conservation of structural and functional features in a primordial CD80/86 molecule from rainbow trout (Oncorhynchus mykiss), a primitive teleost fish. J Immunol 2009;183: 83-96.

[42] Freer G, Burkhart C, Ciernik I, Bachmann MF, Hengartner H, Zinkernagel RM. Vesicular stomatitis virus Indiana glycoprotein as a T-cell-dependent and independent antigen. J Virol 1994;68:3650-5.

[43] Bachmann MF, Kundig TM, Kalberer CP, Hengartner H, Zinkernagel RM. Formalin inactivation of vesicular stomatitis virus impairs T-cell- but not Thelp-independent B-cell responses. J Virol 1993;67:3917-22.

[44] Milich DR, McLachlan A. The nucleocapsid of hepatitis B virus is both a T-cell-independent and a T-cell-dependent antigen. Science 1986;234: 1398-401.

[45] Ray NB, Ewalt NB, Lodmell DL. Nanogram quantities of plasmid DNA encoding the rabies virus glycoprotein protect mice against lethal rabies virus infection. Vaccine 1997; 15:892-5.
[46] Metcalf TU, Baxter VK, Nilaratanakul V, Griffin DE. Recruitment and retention of $B$ cells in the central nervous system in response to alphavirus encephalomyelitis. J Virol 2013;87:2420-9.

[47] Wang T, Hanington PC, Belosevic M, Secombes CJ. Two macrophage colonystimulating factor genes exist in fish that differ in gene organization and are differentially expressed. J Immunol 2008;181:3310-22.

[48] Sallusto F, Kremmer E, Palermo B, Hoy A, Ponath P, Qin S, et al. Switch in chemokine receptor expression upon TCR stimulation reveals novel homing potential for recently activated T cells. Eur J Immunol 1999;29:2037-45.

[49] Nakayama T, Hieshima K, Izawa D, Tatsumi Y, Kanamaru A, Yoshie O. Cutting edge: profile of chemokine receptor expression on human plasma cells accounts for their efficient recruitment to target tissues. J Immunol 2003;170:1136-40.

[50] Imbeault M, Ouellet M, Giguere K, Bertin J, Belanger D, Martin G, et al. Acquisition of host-derived CD40L by HIV-1 in vivo and its functional consequences in the B-cell compartment. J Virol 2011;85:2189-200. 